\title{
Embryonic development of four species of palaemonid prawns (Crustacea, Decapoda): pre-naupliar, naupliar and post-naupliar periods
}

\author{
Yara Müller, Dib Ammar \& Evelise Nazari
}

Departamento de Biologia Celular, Embriologia e Genética, Universidade Federal de Santa Catarina. Caixa Postal 476, 88010-970, Florianópolis, Santa Catarina, Brasil. E-mail: yararm@ccb.ufsc.br

\begin{abstract}
The embryonic development of four species of the family Palaemonidae was studied under laboratory conditions. Adults of Macrobrachium olfersi (Wiegman, 1836), Macrobrachium potiuna (Müller, 1880), Palaemon pandaliformis (Stimpson, 1871) and Palaemonetes argentinus (Nobili, 1901) were collected in Santa Catarina Island, Santa Catarina, Brazil and maintained at $26^{\circ} \mathrm{C}$. The following embryonic characters were analyzed: egg shape, yolk organization and cleavage plane, naupliar and post-naupliar appendages, stomodeum, optical lobes, eyes, telson, embryo curvature and the space occupied by the embryo in the egg. Different rates of development were observed for the four species, with M. potiuna showing the longest time of embryogenesis. The species studied followed the pattern of embryogenesis of centrolecithal eggs, enabling the identification of similar features of the development, and the establishment of eight common embryonic stages.
\end{abstract}

KEY WORDS. Centrolecithal eggs, developmental stages, embryonic morphological features, Macrobrachium.

RESUMO. Foi estudado o desenvolvimento embrionário de quatro espécies de Palaemonidae em condições controladas de laboratório. Adultos de Macrobrachium olfersi (Wiegman, 1836), Macrobrachium potiuna (Müller, 1880), Palaemon pandaliformis (Stimpson, 1871) e Palaemonetes argentinus (Nobili, 1901) foram coletados na Ilha de Santa Catarina, SC, Brasil e mantidos à temperatura de $26^{\circ} \mathrm{C}$. Foram analisadas as seguintes características embrionárias: forma do ovo, organização do vitelo e planos de clivagem, apêndices naupliares e pós-naupliares, estomodeo, lobos ópticos, olhos, telson, curvatura do embrião e o espaço ocupado pelo embrião no ovo. Diferentes ritmos de desenvolvimento foram observados espécies, sendo que M. potiuna mostrou o maior tempo de embriogênese. As espécies seguem o padrão de embriogênese de ovos centrolécitos, sendo identificadas características similares do desenvolvimento, possibilitando o estabelecimento de oito estágios embrionários, comuns as quatro espécies. PALAVRAS CHAVE.Características morfológicas embrionárias, estágios do desenvolvimento, ovos centrolécitos, Macrobrachium.

The quantity and disposition of yolk in the eggs of different crustacean species is closely related to cleavage and embryonic development patterns (ANDERson 1982, Fioroni 1992).

Holoblastic or total cleavage usually occurs in eggs containing a small amount of yolk (oligolecithal eggs), in which the establishment of morphological characteristics occurs relatively fast, resulting in the development of the typical free nauplius larvae with three pairs of appendages (WILLIAMson 1982, Hertzler 2002). This pattern is observed in most branchiopods and maxillopods, and in penaeids of the Malacostraca (Zilch 1978, Hertzler \& Clark 1992).

Crustaceans with yolky eggs (centrolecithal eggs) present meroblastic or partial cleavage. The large amount of yolk triggers a delayed embryonic development that results in further structuring of the embryonized-nauplius (also called egg-nauplius), with the formation of paired appendages, growth of the caudal papilla and organization of appendages in the post- naupliar region (Helluy \& Beltz 1991, Scholtz 2000). This pattern is observed in most malacostracans in which the hatching form is the zoea (Anderson 1982, Williamson \& Rice 1996).

Palaemonid females carry centrolecithal eggs in an external brood pouch during the development time (MüLler et al. 1999, Ammar et al. 2001). This peculiarity of the palaemonids allows a systematic tracking of the embryonic development. MülLER (1984) described the embryogenesis of Macrobrachium carcinus (Linnaeus, 1758), and BRESSAN \& MülLER $(1997,1999)$ characterized the developmental stages of Macrobrachium acanthurus (Wiegmann, 1836). However, most of the research on the ontogeny of this family has focused in the larval development, which was characterized for Macrobrachium olfersi by Dugger \& Dobkin (1975), Macrobrachium amazonicum (Heller, 1862) by MagalHães (1985), Macrobrachium nattereri (Heller, 1862) by Magalhães (1989), and Macrobrachium iheringi (Ortmann, 1897) by Bueno \& Rodrigues (1995). 
The aim of this study was to characterize the embryonic development of four brackish and freshwater palaemonid species, and to establish a relationship between the appearance of the embryonic structures and the total development time.

\section{MATERIAL AND METHODS}

Adult male and female palaemonids were captured at three different areas in Santa Catarina Island. Macrobrachium olfersi (Wiegmann, 1836) was captured in streams with sand, gravel bottoms with no tree or shrub cover at their margins. Macrobrachium potiuna (Müller, 1880) was captured in stoneybottomed streams with a large amount of tree cover at their margins. These two species were collected in freshwater. Palaemon pandaliformis (Stimpson, 1871) and Palaemonetes argentinus (Nobili, 1901) were collected in a muddy-bottomed channel with typical mangrove vegetation at the margins (mean salinity of $20 \%$ ).

Males and females of each species were kept in the laboratory under a $12 \mathrm{~h}: 12 \mathrm{~h}$ photoperiod, $26^{\circ} \mathrm{C}( \pm 2)$, constant aeration and fed daily with pellet food (Tetra ${ }^{\hat{a}}$ plecomin) to obtain ovigerous females. During the study, all ovigerous females were submitted to the same experimental conditions.

Samples of eggs were obtained after spawning at $24 \mathrm{~h}$ intervals, fixed in alcoholic Bouin's fluid and stored in $70 \%$ alcohol.

Egg length and width of pre-naupliar, naupliar and postnaupliar stages were measured using an optical microscope with eyepiece graticule (40x). The number of egg samples was determined by the equation $n=1,96 . s / l$, where $s=$ standard deviation of the initial sample (five eggs) and $l=10 \%$ of the average of the initial sample. Difference in mean egg size and time of hatching between species was tested using ANOVA (Tukey's test).

The following developmental features were observed at a magnification of 40x: egg shape, arrangement of the chorion and yolk organization, appearance of cleavage furrows and blastomeres, development of the germinal disc, organization of naupliar appendages, stomodeum and optical lobes, appearance of the post-naupliar appendages, development of the eyes, telson formation, curvature of the embryo and space occupied by the embryo in the egg.

\section{RESULTS}

The species studied can be considered medium sized palaemonids, with $M$. olfersi females presenting the largest length and weight (Tab. I). This species also carry much more eggs than the others, as the mean fecundity observed in ovigerous females was 1557. M. potiuna females, in contrast, carry an average of only 40 eggs.

The eggs of all species followed a similar pattern of embryogenesis, enabling the establishment of eight common morphological stages.

Stage I: spawning egg - no embryonic structures are vis-
Table I. Length, weight and fecundity data of adult females of the four analyzed palaemonid species.

\begin{tabular}{|c|c|c|c|c|}
\hline \multicolumn{2}{|c|}{ Species } & Length $(\mathrm{mm})^{*}$ & Weight $(\mathrm{g})^{*}$ & Fecundity \\
\hline \multirow[t]{2}{*}{ Freshwater } & M. olfersi & $45.98 \pm 13.40$ & $2.33 \pm 1.10$ & $1557 \pm 937$ \\
\hline & M. potiuna & $31.96 \pm 5.00$ & $0.57 \pm 0.30$ & $40 \pm 14$ \\
\hline \multirow[t]{2}{*}{ Brackish } & P. pandaliformis & $35.34 \pm 6.90$ & $0.33 \pm 0.20$ & $430 \pm 146$ \\
\hline & P. argentinus & $25.25 \pm 3.60$ & $0.20 \pm 0.08$ & $151 \pm 42$ \\
\hline
\end{tabular}

* Data showed in mean and standard deviation.

ible on the surface of the egg. The yolk mass (YM) is evident and presents a pale-yellow coloration, regularly distributed in M. potiuna and granular in M. olfersi, $P$. pandaliformis and $P$. argentinus. The chorion (Ch) is transparent and intimately attached to the vitelline membrane of the egg (Fig. 1).

Stage II: cleavage - blastomeres $(\mathrm{Bl})$ are clearly seen, and due to the organization and the depth of the cleavage furrows (CF), they become evident on the egg surface (Fig. 2). The cleavage furrows appear deeper in M. potiuna and $P$. pandaliformis, since the blastomeres easily separate one from the other. When the blastomeres are removed, the remaining yolk mass can be observed in the internal region of the egg.

Stage III: germinal disc (GD) - small and numerous blastomeres can be observed on the surface of the egg. Some of these blastomeres converge on a predetermined region of the egg, forming the germinal disc (Fig. 3). When seen in dorsal view this presents a V-shape, where the superior extremities correspond to the future optical lobes and the inferior region to the blastoporal area. In P. pandaliformis the embryo presents a U-shape due to the enlargement of the blastoporal area. The cells migrate through the blastoporal area, which will constitute the early germ layers, which contrasts with the yellowish color of the yolk. The germinal disc can be located in the medium or in the extremity of the egg.

Stage IV: embryonized nauplius - in this stage an intense modeling process is observed, clearly defining the boundaries of the embryonic structures. Intense proliferation and organization of the germinal disc result in the establishment of the embryonized nauplius. In the mid-lateral region, rudiments of the three paired naupliar appendages, the so-called antennulae $(\mathrm{An})$, antennae $(\mathrm{At})$ and mandibles $(\mathrm{Mb})$, are organized. In the central region, a depression is formed that corresponds to the stomodeum (St) and, in the posterior extremity, the caudal papilla (CP) is well demarcated (Fig. 4).

Stage V: initial post-nauplius - the embryo grows (Fig. 5) superficially following the long axis of the egg. The optical lobes (OL) are recognized in the embryo cephalic region, and the naupliar appendages (NA) project ventrally towards the caudal papilla. In lateral view, the embryo is lightly bent into a C-shape. Just below the naupliar appendages it is possible to observe the post-naupliar appendages (PnA), which are arranged laterally. The naupliar appendages become biramous 

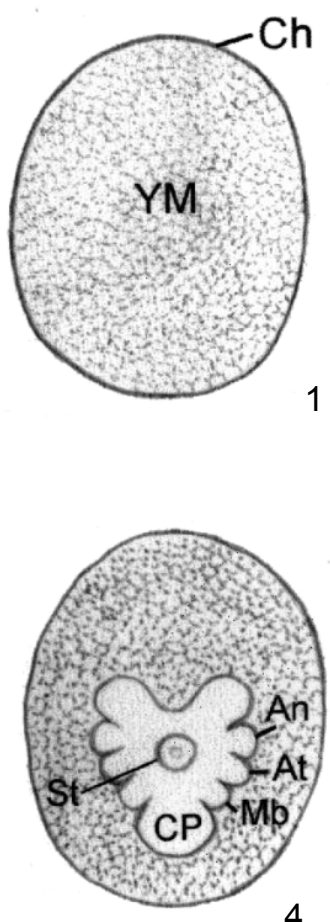

4

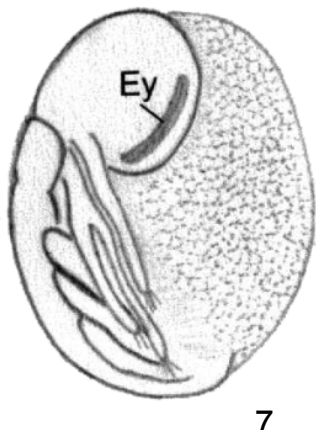

7

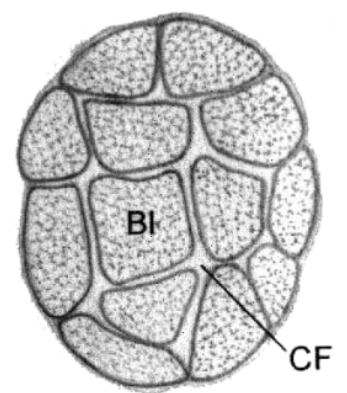

2

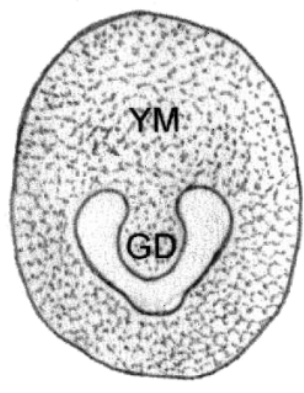

3

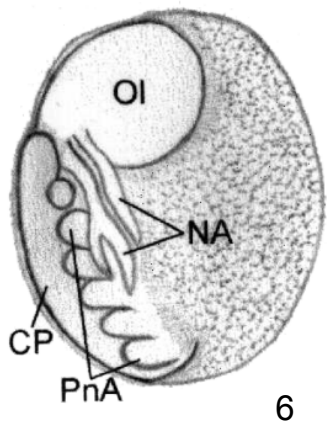

5

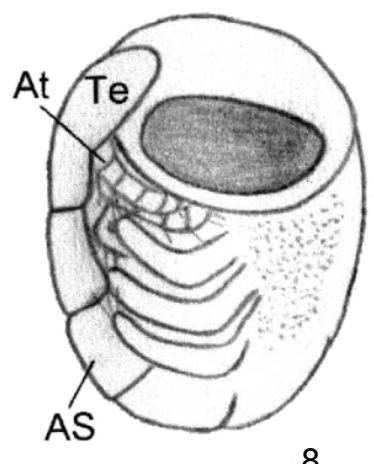

8

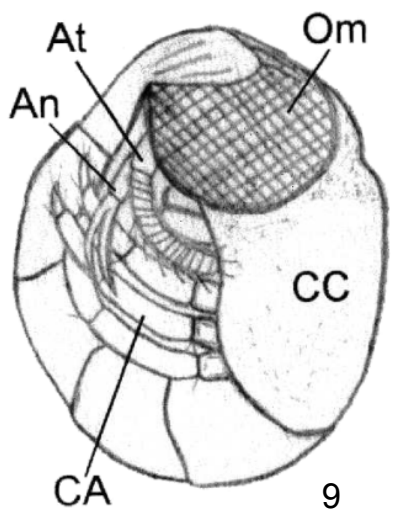

Figures 1-9. Morphological pattern of the embryonic developmental stages of $M$. olfersi, M. potiuna, P. pandaliformis and $P$. argentinus: (1) spawning egg; (2) Cleavage; (3) Germinal disc; (4) embryonized nauplius; (5-6) initial post-nauplius; (7) mid post-nauplius; (8) final post-nauplius; (9) pre-hatching embryo. (An) Antennulae, (AS) abdominal segment, (At) antennae, (BI) blastomeres, (CC) cephalothoracic carapace, (CA) cephalothoracic appendages, (CF) cleavage furrows, (Ch) chorion, (CP) caudal papilla, (GD) germinal disc, (Ey) eye, $(\mathrm{Mb})$ mandibles, (OL) optical lobes, (NA) naupliar appendages, (Om) ommatidia, (PnA) post-naupliar appendages, (St) stomodeum, (Te) telson, (YM) yolk mass. Bars = $0.10 \mathrm{~mm}$ (M. olfersi), $0.12 \mathrm{~mm}$ ( $P$. pandaliformis and $P$. argentinus), $0.30 \mathrm{~mm}(\mathrm{M}$. potiuna).

and display well-defined external limits, and the caudal papilla is well developed and bent (Fig. 6).

Stage VI: mid post-nauplius - the main change is the organization of the eye rudiments in the distal portion of the optical lobes. Initially the eyes (Ey) are thin and elongated, with dark pigmentation that distinguishes them from other embryonic structures. At this stage the body becomes mark- edly curved, and the caudal papilla reaches the optical lobes. The naupliar appendages present setae and grow toward the posterior region. The post-nauplius appendages grow and are projected on the caudal papilla. The yolk mass occupies less space, in the area free from embryonic structures (Fig. 7).

Stage VII: final post-nauplius - the eyes become larger and more oval, defining the anterior region of the embryo. 
The abdominal segments (AS), that will comprise the abdominal region of the developing zoea, become evident. At the posterior extremity of the body is the telson (Te), which due to the pronounced bending of the embryo overlaps the optical lobes. The yolk mass becomes less visible, both because of its decreased size and because of the organization of embryonic structures (Fig. 8).

Stage VIII: pre-hatching embryo - there are no obvious changes in the general external morphology of the embryo. The eyes are larger and rounder, allowing the visualization of the ommatidia $(\mathrm{Om})$. In the cephalothoracic region, the antennulae, antennae and mandibles are more developed. The abdominal region is organized in five segments, the last one being the longest. The cephalothoracic carapace (CC) is formed, covering the heart, the cephalothoracic appendages (CA) and, partially, the first abdominal segment. The transparency of the carapace allows the recognition of yolk granules inside the midgut. Close to hatching, the chorion detaches from the surface of the embryo allowing a greater motility. Hatching occurs in the form of a free larva, the zoea (Fig. 9).

An analysis of the embryonic development stages described in this study enables the recognition of three development periods, the so-called pre-naupliar, naupliar and postnaupliar (Fig. 10). In the pre-naupliar period, which includes the stage I and II, cleavage and early gastrulation occur. The naupliar period corresponds to the stages III and IV, equivalent to the initial morphogenesis, when the crustaceans primitive larval form is recognized. The next stages correspond to the post-naupliar period, which is by far the longest period on all species studied. It is characterized by the bending of the caudal papilla and the growth of the naupliar and post-naupliar structures. The time in days of these three periods for each species is represented on figure 10. M. potiuna shows the longer developmental time than the other three species, mainly due to the larger extent of the Post-naupliar period.

The size of the eggs increased in all four species during embryogenesis. The long axis shows a more pronounced growth than the short axis, resulting in a change in the shape of the egg. In the species studied, the egg becomes more oval in the latter period of development (Tab. II). The variation of both axes from the Pre and Naupliar stages to the Post-naupliar stage presented no significant differences (ANOVA) in M. olfersi, $P$. argentinus and $P$. pandaliformis.

\section{DISCUSSION}

The characterized stages of embryonic development in palaemonids followed the general pattern of embryogenesis described for other species that have centrolecithal eggs, as Palaemonetes varians (Leach, 1814) (Weygoldt 1961), Macrobrachium carcinus (Linnaeus, 1758) (MülLer 1984), Palaemonetes pugio (Glas et al. 1997), Macrobrachium acanthurus (Wiegman, 1836) (BRessan \& Müller 1999).

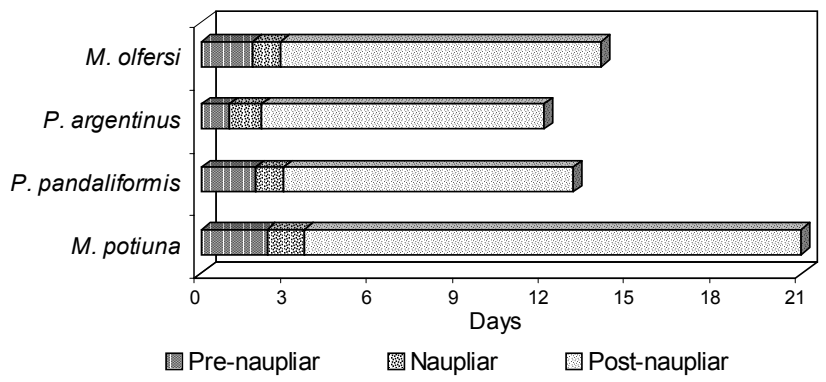

Figure 10. Representation of pre-naupliar, naupliar and postnaupliar periods of embryonic development of four palaemonid species.

The formation of the naupliar structures follows the organization of the basic body plan observed in the development of oligolecit species eggs (Hertzler \& Clark 1992, NAZARI et al. 1998) where first larval phases correspond to the embryonized post-nauplius in the meroblastic pattern (ТАLвоT \& Helluy 1995).

The cleavage process observed in stage II indicates that development follows a holoblastic pattern, since cleavage furrows can be seen in the surface of the whole egg, individualizing the blastomeres. However, these cleavage furrows are shallow, and they do not reach the central yolk mass. The subsequent organization of the germinal disc seen in stage III, followed by the organization of the embryonized nauplius and post-nauplius, are typical of the meroblastic developmental pattern (WEYGOLDT 1979, MülLER 1984). The recognition of both holoblastic and meroblastic developmental traits during the cleavage stage is common in most decapod species, due to the particular quantity and distribution of the yolk in the eggs (ANDERSON 1982).

The development of the palaemonid species analyzed show that the initial morphogenesis is quite intense until organization of the embryonized nauplius. The nauplius could be visualized due to the large size of the egg, superficial position of the embryo and color contrast between embryonic cells and yolk mass.

In the present study, the egg size of the palaemonids species analized increased mainly in long axis during the embryonic development. These changes in egg size were also reported to most malacostracan species, as the brachyuran Eriocheir japonicus (De Haan, 1835) (КовAYASHI \& MATSUURA 1995) and the prawn M. olfersi (Mossolin \& Bueno 2002). According to Odinetz-Collart \& Rabelo (1996) and Narciso \& Morais (2001), in crustaceans the egg diameter tends to increase until hatching. The growth of egg size is associated, among other factors, to the increase of water content in eggs, as the embryo develops (КоBaYashi \& MatsuURa 1995).

In crustacean with yolky eggs, different developmental 
Table II. Mean egg size and timing of embryonic development in the four analyzed palaemonids species.

\begin{tabular}{|c|c|c|c|c|c|c|c|c|c|c|}
\hline \multirow{3}{*}{$\begin{array}{r}\text { Species } \\
\text { M. olfersi }(n=15)\end{array}$} & \multicolumn{5}{|c|}{ Pre and Naupliar stage* } & \multicolumn{3}{|c|}{ Post-naupliar stage* } & \multirow{2}{*}{\multicolumn{2}{|c|}{$\begin{array}{l}\text { Development } \\
\text { (days)* }^{*}\end{array}$}} \\
\hline & \multicolumn{2}{|c|}{ Long axis (mm) } & \multicolumn{2}{|c|}{ Short axis (mm) } & \multicolumn{2}{|c|}{ Long axis (mm) } & \multicolumn{2}{|c|}{ Short axis (mm) } & & \\
\hline & 0.488 & \pm 0.04 & 0.361 & \pm 0.04 & 0.672 & \pm 0.05 & 0.458 & \pm 0.04 & 14 & \pm 1 \\
\hline P. argentinus $(n=15)$ & 0.602 & \pm 0.08 & 0.503 & \pm 0.04 & 0.840 & \pm 0.06 & 0.624 & \pm 0.03 & 12 & \pm 1 \\
\hline P. pandaliformis $(\mathrm{n}=15)$ & 0.677 & \pm 0.06 & 0.547 & \pm 0.02 & 0.948 & \pm 0.07 & 0.776 & \pm 0.04 & 13 & \pm 1 \\
\hline M. potiuna $(\mathrm{n}=15)$ & $1.670^{*}$ & ${ }^{*} \pm 0.10$ & $1.305^{\star}$ & ${ }^{*} \pm 0.08$ & $1.950^{*}$ & \pm 0.10 & $1.505^{*}$ & \pm 0.09 & $21^{*}$ & \pm 2 \\
\hline
\end{tabular}

$\left(^{*}\right)$ Data showed in mean and standard deviation; $\left(^{* *}\right)$ indicates significant statistical variation between stages ANOVA $(p \geq 0,05)$.

times are observed from spawning to hatching, such as 40 days for Cherax destructor (SANDEMAN \& SANDEMAN 1991) and 180 days for Homarus americanus (Helluy \& Beltz 1991). These different incubation times are related to the endogenous factors of development and can also be influenced by exogenous factors like water temperature, as described by Celada et al. (1991). However, in this study the water temperature was controlled, suggesting that the endogenous factors, like egg size and the amount of yolk, were determinant to the variation of the development time.

The species M. olfersi, $P$. pandaliformis and P. argentinus all have similar sized eggs and have presented similar development times. On the other hand, the longest length of development was observed in M. potiuna, whose voluminous eggs allowed for a more prolonged embryogenesis, which results on a development of more complex structures. According to JALIHAL et al. (1993), the species of Macrobrachium, which have larger eggs, tend to show a smaller fecundity, fewer larval stages, and a reduction of the larval period. These features have also been observed in other palaemonids, such as Macrobrachium nattereri (Magalhães 1989), Macrobrachium iheringi (Bueno \& Rodrigues 1995), Macrobrachium borellii (Bond \& BucKup 1982) and Macrobrachium jelskii (GAMBA 1984).

A similarity of the length of the embryonic periods, established in this study, shows that a specific amount of time to the organization of embryonic features is necessary. The prenaupliar and naupliar periods are faster due the organization of less complex embryonic structures. The post-naupliar period is longer because the structures have to be finalized and to acquire functionality before hatching. In M. potiuna the postnaupliar stage is even longer, because this species hatches as a more complex lavae.

These results suggest that the egg size is a very important factor to embryonic development time and consequently the duration of pre-naupliar, naupliar and post-naupliar periods. However, equivalent morphogenetic process is observed in these four species, which enables a characterization of a morphologic development pattern to the yolky egg palaemonids.

\section{REFERENCES}

Ammar, D.; Y.M.R. Müller \& E.M. Nazari. 2001. Biologia reprodutiva de Macrobrachium olfersii (Wiegman) (Crustacea, Decapoda, Palaemonidae) coletados na Ilha de Santa Catarina, Brasil. Revista Brasileira de Zoologia, Curitiba, 18 (2): 529-537.

Anderson, D.T. 1982. Embryology, p. 1-41. In: L.G. Abele (Ed.). Embryology, morphology and genetics. New York, Academic Press, XIX+495p.

Bond, G. \& L. BucKuP. 1982. O ciclo reprodutor de Macrobrachium borelli (Nobili, 1896) e Macrobrachium potiuna (Müller, 1880) (Crustacea, Decapoda, Palaemonidae) e suas relações com a temperatura. Revista Brasileira de Biologia, Rio de Janeiro, 42 (3): 473-782.

Bressan, C.M. \& Y.M.R. Müller. 1997. Characterization of embryonized nauplius development of Macrobrachium acanthurus (Crustacea, Decapoda). Brazilian Journal of Morphological Sciences, São Paulo, 14 (2): 243-246.

. 1999. Postnaupliar embryonic development of Macrobrachium acanthurus (Crustacea Decapoda). Brazilian Journal of Morphological Sciences, São Paulo, 16 (2): 155-160.

Bueno, S.L.S. \& S.A. Rodrigues. 1995. Abbreviated larval development of the freshwater prawn, Macrobrachium iheringi (Ortmann, 1897) (Decapoda, Palaemonidae), reared in the laboratory. Crustaceana, Leiden, 68 (6): 665-686.

Celada, J.D.; J.M. Carral \& J. Gonzalez. 1991. A study on identification and chronology of the embryonic stages of the freshwater crayfish Austropotamobius pallipes (Lereboullet, 1858). Crustaceana, Leiden, 61 (3): 225-232.

Dugger, D.M. \& S. Dobkin. 1975. A contribution to knowledge of the larval development of Macrobrachium olfersii (Wiegman, 1836) (Decapoda, Palaemonidae). Crustaceana, Leiden, 29 (1): 1-30.

GAMBA, L. 1984. Different egg-associated and larval development characteristics of Macrobrachium jelskii and Macrobrachium amazonicum (Arthropoda: Crustacea) in a Venezuelan continental lagoon. Journal of Invertebrate Reproduction and Development, Rehovot, 7: 135-142. 
FIORONI, P. 1992. Allgemeine und vergleichende Embryologie der Tiere. Berlin, Springer Verlag, XII+429p.

Glas, P.S.; L.A. Courtney; J.R. Rayburn \& W.S. Fisher. 1997. Embryonic coat of the grass shrimp Palaemonetes pugio. Biological Bulletin, Woods Hole, 192: 231-242.

Helluy, S.M. \& B.S. Beltz. 1991. Embryonic development of the american lobster (Homarus americanus): quantitative staging and characterization of an embryonic molt cycle. Biological Bulletin, Woods Hole, 180: 355-371.

Hertzler, P.L. \& W.H. Jr. Clark. 1992. Cleavage and gastrulation in the shrimp Sicyonia ingentis: invagination is accompanied by oriented cell division. Development, Cambridge, 116: 127-140.

Hertzler, P.L. 2002. Development of the mesendoderm in the Dendobranchiata shrimp Sicyonia ingentis. Arthropod Structure and Development, Oxford, 31: 33-49.

JALIHAL, D.R.; K.N. SANKOLLI \& S. SHENOY. 1993. Evolution of larval developmental patterns and the process of freshwaterization in the prawn genus Macrobrachium Bate, 1868 (Decapoda, Palaemonidae). Crustaceana, Leiden, 65 (3): 365-376.

Ковауashi, S. \& S. Matsuura. 1995. Egg development and variation of egg size in the japanese mitten crab Eriocheir japonicus (De Haan). Benthos Research, Kumamoto, 48: 2939.

Magalhães, C. 1985. Desenvolvimento larval obtido em laboratório de palemonídeos da Região Amazônica. I. Macrobrachium amazonicum (Heller, 1862) (Crustacea, Decapoda). Amazoniana, Manaus, 2: 247-274.

- 1989. The larval development of palaemonid shrimps from the Amazon Region reared in the laboratory. VI. Abbreviated development of Macrobrachium nattereri (Heller, 1862) (Crustacea, Decapoda). Amazoniana, Manaus, 4: 379-392.

Mossolin, E.C. \& S.L.S. Bueno. 2002. Reproductive biology of Macrobrachium olfersi (Decapoda, Palaemonidae) in São Sebastião, Brazil. Journal of Crustacean Biology, Woods Hole, 22 (2): 367-376.

Müller, Y.M.R. 1984. Die Embryonalentwicklung von Macrobrachium carcinus (L.) (Malacostraca, Decapoda, Natantia). Zoological Jahrbücher Anatomie, Jena, 112: 5178.

Müller, Y.M.R.; E.M. Nazari; D. Ammar \& E.C. Ferreira. 1999. Biologia dos Palaemonidae (Crustacea, Decapoda) na bacia hidrográfica de Ratones, Florianópolis, Santa Catarina, Brasil. Revista Brasileira de Zoologia, Curitiba, 16 (3): 629636.

Narciso, L \& S. Morais. 2001. Fatty acid profile of Palaemon serratus (Palaemonidae) eggs and larvae during embryonic and larval development using different live diets. Journal of Crustacean Biology, Woods Hole, 21 (3): 566-574.

Nazari, E.M.; D. Ammar; R.L. Petersen \& Y.M.R. Müller. 1998. Desenvolvimento embrionário do camarão rosa Penaeus paulensis (Perez Farfante, 1967) (Crustacea, Decapoda). Anais Aquicultura Brasil'98, Recife, 2641-648.

Odinetz-Collart, O. \& H. Rabelo. 1996. Variation in egg size of the fresh-water prawn Macrobrachium amazonicum (Decapoda: Palaemonidae). Journal of Crustacean Biology, Woods Hole, 16 (4): 684-688.

Sandeman, R. \& D. Sandeman. 1991. Stages in the development of the embryo of the fresh-water crayfish Cherax destructor. Roux's Archives of Development Biology, Berlin, 200: 2737.

Scholtz, G. 2000. Evolution of the nauplius stage in malacostracan crustaceans. Journal of Zoological Systematics and Evolutionary Research, Berlin, 38: 175-187.

Talbolt, P. \& S. Helluy. 1995. Reproduction and embryonic development, p. 177- 216. In: J.R. FACTOR (Ed.). Biology of the lobster Homarus americanus. New York, Academic Press, XIV+561p.

Weygoldt, P. 1961. Beitrag zur kenntnis der ontogenie der Dekapoden: embryologische untersuchungen an Palaemonetes varians (Leach). Zoologische Jahrbücher Anatomie, Jena, 79: 223-270.

Weygoldt, P. 1979. Significance of later embryonic stages and head development in Arthropod phylogeny, p. 107-131. In: A.P. Gupta (Ed.). Arthropod phylogeny. New York, van Nostrand - Reinhold Company, XX+762p.

Williamson, D.I. 1982. Larval morphology and diversity, p. 43110. In: L.G. Abele (Ed.). Embryology, morphology and genetics. New York, Academic Press, XIX+495p.

Williamson, D.I. \& A.L. Rice. 1996. Larval evolution in the Crustacea. Crustaceana, Leiden, 69 (3): 267-287.

ZILCH, R. 1978. Embryologische Untersuchungen von der holoblastischen Ontogenese von Penaeus trisulcatus Leach (Crustacea, Decapoda). Zoomorphologie, Heidelberg, 90: 67-100.

Received in 28.III.2003; accepted in 15.I.2004. 